UDC 621.397.62: 621.397.132

\title{
カラーテレビジョン装置における 新高圧安定系の開発とその動作解析
}

\author{
株式会社日立製作所家電研究所広田亮一・明石吉三 \\ 松 本 脩 三・宮崎源太郎
}

カラーテレビジョン装置においてブラウン管のアノードに加える高電圧を安定化するため, 従来 は高耐圧の真空管を使用していた。しかし，ての方式は信頼性が非常に低かったので，リアクタを 利用したまったく新しい安定系を開発し，装置の全半導体化を促進した．との安定系は系の低圧側 で動作させているため, 從来の方式に比較して非常に信頼性が高く, 消費電力が少ない等の利点を 有している. ここでは, 新しく開発した安定系の動作原理, 実用回路について述べるとともに等価 回路を誘導して動特性を検討した。

\section{1. まえがき}

カラーテレビ装置において，受像管の陽極に加える高 圧は，水平帰線期間に水平偏向出力トランジスタのコレ クタに生ずるパルスを，水平出力トランス（以下 FBT と略称する) で昇圧し，整流して得ている。しかし，乙 のようにして得た高圧は，負荷電流に対するレギュレー ションが充分でないため，カラーテレビ装置に执いては 何らかの方法で安定化する必要がある。

白黒テレビ装置では，高圧を安定化する必要がなく， 特にカラーテレビ装置において安定化が必要である理由 は次のとおりである.

カラーテレビ装置においては，カラ一受像管のビーム 電流が大きいうえに $(1 \mathrm{~mA}$ 程度で白黒受像管の約 5 倍), 映像信号は直流再生を行なっているので, 平均ビ 一ム電流が画面によって大幅に変動する。

このため, 受像管の陽極に加える高圧を安定化しない と，ビーム電流の変化によって高圧が大幅に変わり，う スターの振幅変化，コンバーゼンスずれ，ホーカスぼけ など，望ましくない現象を起こしてしまう。

このような高圧変動を防ぐために，従来の真空管式力 ラーテレビ装置においては，通常，高圧出力に並列に高 耐圧の真空管を用いて高圧を安定化するシャントレギュ レーター方式を使用していた。

"Development and Analysis of New High Voltage Regulation "Development and Analysis of New High Voltage Regulation Akashi, Shũzó Matsumoto and Gentaró Miyazaki. (Consumer Electronics Laboratory, Hitachi, Ltd., Yokohama). テレビジョン 学会方式回路研究委員会発表 (昭45.8)
しかし，てのシャントレギュレーター方式は，次のよ うな重大な欠点がある。

（1） 発熱量が多くスペースをとる.

(2) 寿命が短い.

（3） X線を放射する.

したがって，カラーテレビ装置を半導体化するにあた って，シャントレギュレーター方式にとってかわる新ら しい高圧安定方式が必要之なった。

筆者らは，そのひとつの方式として，先に示した欠点 を改善した新引しい高圧安定方式を開発した ${ }^{1)}$ 。この方 式は，FBT の低圧側に可飽和リアクタを使用し，高圧 の変化住じて，とのリアクタのインダクタンスを変化 させて，高圧を安定化する方式である（以下，乙の方式 をリアクタ制衘方式と称する).

したがって，乙の方式は従来のシャントレギュレータ 一方式のように，安定化にとあなう熱損失はほとんぞな く，しかあ安定で信頼性が高く，X線の放射むないとい う特長を有している。

ここでは，乙の方式の原理，実際に適用した回路につ いて述べささらに，ての方式の線形回路素子のみで構成 される等価回路を誘導して, 動特性を解析し, 制御系の 安定性を理論的に検討した。

なお，従来のシャントレギュレータ一方式にとってか わるべき他の方式として, FBT の低圧側に並列に接続さ れる容量を等洒的に変化させる方式がリアクタ制御方式 の文献1)より 1 年遅れて発表され22，実用化されている. しかし,ての容量を変化させる方方式は, 受像管内の電極 
間放電の際，異常電压を発生する FBT 端子にトランジ スタ，ダイオード等の半導体素子を接続するため, リア クタ方式のような高い信頼性を得ることは困難である. また, 使用するトランジスタは, 高耐压の電力トランジス タを必要とするため, コストの面です不利と考えられる.

\section{2. リアクタ制御方式の概要}

\section{1 動作原理}

図 1 は本方式による高圧安定制御方式の原理を説明す る図で, 水平偏向コイルに並列にインダクタンス可変の 制御リアクタが接続されており, 高圧変動に応じてての インダクタンスの值を変化させて高圧を安定化すること が基本原理である.

図 1 で TR は水平出力トランジスタ, $\mathrm{D}_{1}$ はダンパーダ イオード，C は共振コンデンサ， $L_{y}$ は水平偏向コイル, $\mathrm{D}_{2}$ は高圧整流用ダイオード， $L_{x}$ は高圧制御並列リアク タ， $V_{C C}$ は電源電圧である。般に FBT の低圧巻線の インダクタンス $L_{F}$ は, 水平偏向コイル (以下単にDY という）のインダクタンス $L_{y}$ にくらべ10 倍程度も大 きいから， $L_{F}$ は省略して考える. 制御リアクタのイン ダクタンスを $L_{x}$ とすると, 1 次側の全並列インダクタ ンスは，

$$
L_{t}=\frac{L_{x} \cdot L_{y}}{L_{x}+L_{y}}
$$

である．後に示すように，コレクタパルス電圧の最大值 が $L_{t}$ の平方根に逆比例するから， $L_{x}$ を変化させるこ とにより，受像管陽極電圧（以下単に高圧という）を変 化させることができる，次にこれを説明する.

（1）可飽和リアクタのない場合 ${ }^{3}$ （従来の高圧偏向 回路の場合)

基本回路で $L_{x}$ がない場合である．以下，説明を簡単 にするため回路の損失は無視する. 図 2 は高圧偏向回路 の動作波形で， $i_{y}$ は DY に流れる電流， $e_{c}$ は水平出力 トランジスタのコレクタ電圧波形， $t_{1} \rightarrow t_{3}$ は走查期間, $t_{3} \rightarrow t_{1}$ は帰線期間である. 走査期間の中央を $t_{2}$ とすると

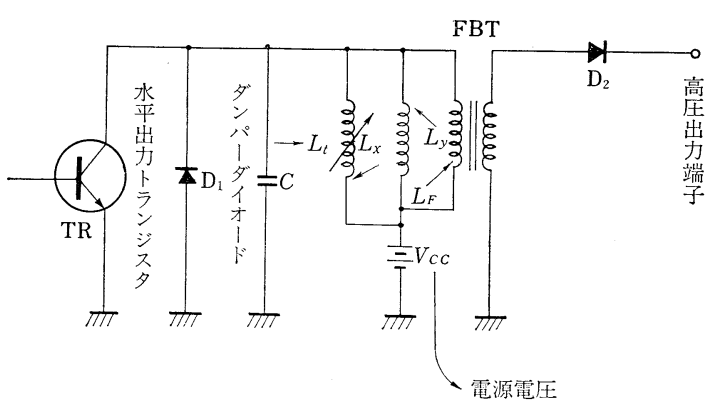

図 1 リアクタ制御方式の原理を説明する回路図 Fundamental circuit diagram explaining the principle.

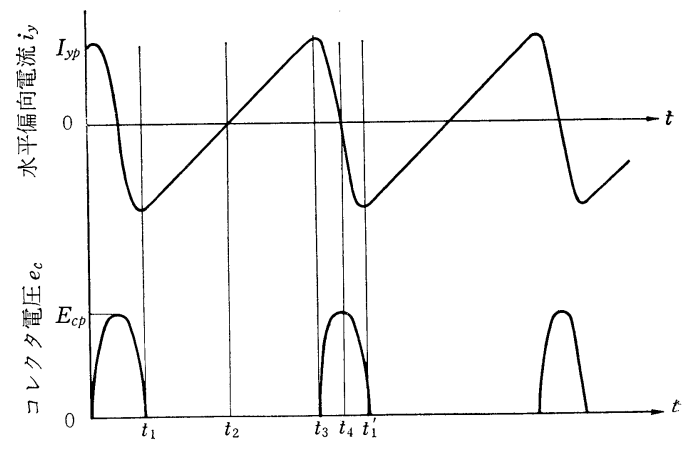

図 2 出力回路の動作波形

Operating waveforms of the horizontal output stage.

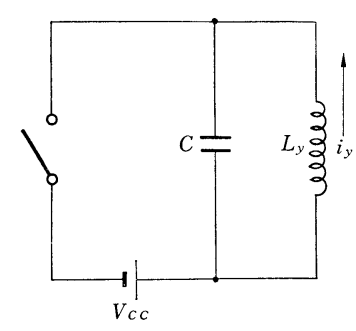

図 3 走查期間の等価回路 Equivalent circuit of scanning period.

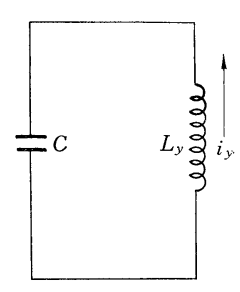

図 4 帰線期間の 等価回路 Equivalent circuit of retrace period. $t_{2} \leqq t \leqq t_{3}$ では，水平出力トランジスタ TR は尊通する. そのときの等価回路は図3である。したがって,

$$
i_{y}=\frac{V_{C C}}{L_{y}}\left(t-t_{2}\right)
$$

次に $t=t_{3}$ で, $i_{y}$ は最大值 $I_{y p}$ に達する. その值は,

$$
I_{y p}=\frac{V_{C C}}{L_{y}}\left(t_{3}-t_{2}\right)=\frac{V_{C C}}{L_{y}} \cdot \frac{T_{s}}{2}
$$

ここで $T_{s}$ は走査期間である.

その後, 水平出力トランジスタ TRは遮断状態になり, 州線期間に入る. 次に帰線期間の動作を説明する.

コレクタが迕断されると，DYに流れていた電流 $i_{y}$ は $L_{y}$ と $C$ で並列共振を生ずる，そのときの等価回路は 図 4 に示す. この帰線期間では近似的に $L_{y}$ に流れる電. 流は,

$$
i_{y} \fallingdotseq I_{y p} \cos \frac{\left(t-t_{3}\right)}{\sqrt{L_{y} C}}
$$

また、コレクタ電圧 $e_{c}$ は，

$$
e_{c} \fallingdotseq-L_{y} \frac{d i_{y}}{d t}=I_{y p} \sqrt{\frac{L_{y}}{C}} \sin \frac{\left(t-t_{3}\right)}{\sqrt{L_{y} C}}
$$

である. 共振周期のほぼ $1 / 4$ 周期の時点 $t=t_{4}$ で $e_{c}$ は 最大值を得る. その值を $E_{c p}$ とすれば,

$$
E_{c p}=I_{y p} \sqrt{\frac{L_{y}}{C}}
$$

である.さらに $I_{y p}$ に (2) 式を代入すると, 


$$
E_{c p}=\frac{V_{C C}}{\sqrt{L_{y} C}} \cdot \frac{T_{s}}{2}
$$

となる. $t=t_{1}{ }^{\prime}$ 後, $i_{y}$ の振幅減少とともに負の電圧を発 生しようとするが，ダンパーダイオードが導通し，走査 期間に移り, DY の雨端に電源電圧 $V_{C C}$ が加わり， $i_{y}$ は 負のピーク值一 $I_{y p}$ から 0 まで増加し，水平出力トラン ジスタが導通し，最初の状態にもどる.

\section{（2）可飽和リアクタのある場合14)}

可飽和リアクタのある場合, 2.1 節 (1) 項の $L_{y}$ を $L_{t}$ と考えればよいから， $L_{t}$ に流れる電流のピーク值 $I_{c p}$, コレクタピーク電圧 $E_{c p}$ は $(2), \quad(6)$ 式で $L_{y}$ に $L_{t}$ を代入してそれぞれ，

$$
\begin{aligned}
& I_{c p}=\frac{V_{C C}}{L_{t}} \cdot \frac{T_{s}}{2} \\
& E_{c p}=\frac{V_{C C}}{\sqrt{L_{t} C}} \cdot \frac{T_{s}}{2}
\end{aligned}
$$

となる.（8)式はコレクタパルス電圧のピーク值 $E_{c p}$ が 全並列インダクタンス $L_{t}$ の平方根に逆比例するととを 示している，いま屯し，高圧負荷電流が増加して，高圧 が低下したときには，その不足分を補うだけ $E_{c p}$ を増加 させ机ばよく，そのためには全並列インダクタンス $L_{t}$ を減少させればよい， $L_{t}$ は $L_{x}$ と $L_{y}$ の並列合成值で あるから，制御リアクタ $L_{x}$ を減少させるととにより， 高圧を安定化することができる.

なお， $L_{y}$ と $L_{x}$ は直流電源と水平出力トランジスタ のコレクタとの間に並列に接続されているので, $L_{x}$ が 変化してあ $L_{y}$ に流れる電流は変化せず, したがって, $L_{x}$ の変化はラスターの水平サイズに悪影響を与えるこ とはない.

\section{2 実用回路の概要}

前節で述べた，制御リアクタのインダクタンスを高圧 の変動に応じて変化させる方法は種々考えられる．本節 では実用した方式の概略を述べる114).

実用回路は図 5 に示すように, 䛊差信号として高圧負 荷電流（以下単にビーム電流と略称する）に応じて変化 する直流電源電流を利用している.

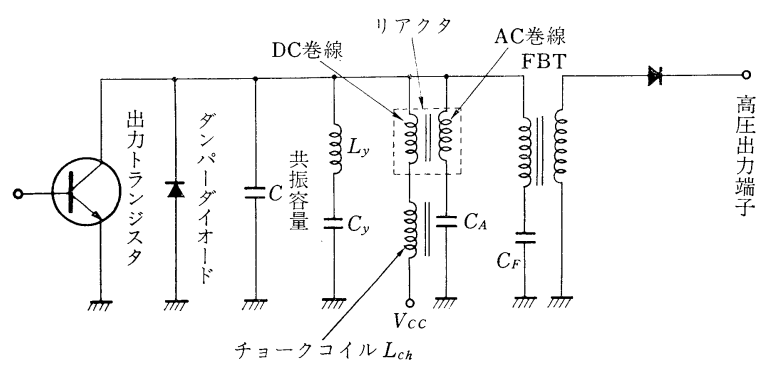

図 5 リアクタ制御の実用回路

Practically applied system using the regulating reactor.

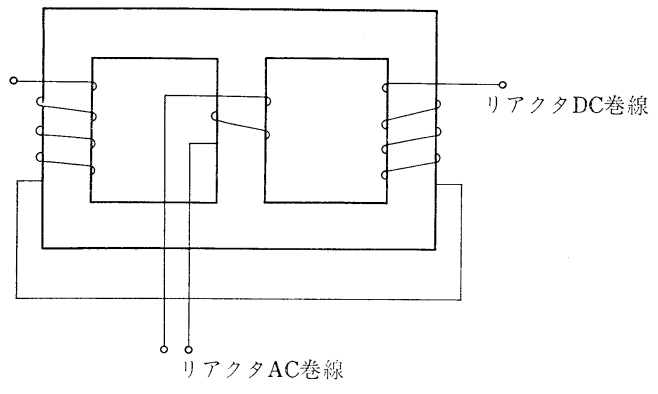

図 6 制御リアクタの巻線構造

Winding structure of the reactor.

制御リアクタは, フェライトのコアに DC 巻線と $\mathrm{AC}$ 巻線を巻いたものである. DC 巻線に流れる電流が堌加 すると，コアが飽和して， $\mathrm{AC}$ 巻線のインダクタンス $L_{x}$ が減少するようになっている。 $C_{F}$ は FBT 1 次巻線 とアース間の容量, $C_{A}$ は $\mathrm{AC}$ 巻線とアース間の容量, $C_{y}$ は $\mathrm{S}$ 字補正用容量である

電源電圧 $V_{C C}$ は，チョークコイル $L_{c h}$ を介して制御 リアクタの DC 巻線に加えられる.ビーム電流が流れて 高圧電力が消費されると，乙の電力を供給するために直 流電源から DC 巻線に流込む電源電流が增加する．ての ため偏向コイルに型列に接続された $\mathrm{AC}$ 巻線のインダク タンス $L_{x}$ が減少し，（8) 式で示したように帰線期間の パルス電圧 $E_{c p}$ が増加し，ビーム電流を流すととによる 高圧の低下を補うように動作し, 高压を安定化している.

なお，制御リアクタは図 6 に示すような巻線構造で, コアの中央の脚に AC 巻線, 両側の脚に DC 巻線が巻 いてある. 両側の DC 巻線は互いに逆相に巻いてあり, $\mathrm{AC}$ 巻線と $\mathrm{DC}$ 巻線の間の交流的な結合がない状態で, $\mathrm{DC}$ 巻線電流の変化によって, $\mathrm{AC}$ 巻線のインダクタン スを変化させることができるようにしてある。

実用化した制御リアクタの外観を写真 1 亿示す。制御 リアクタは DC 巻線に直列に接続するチョークコイルと 一体化されている.

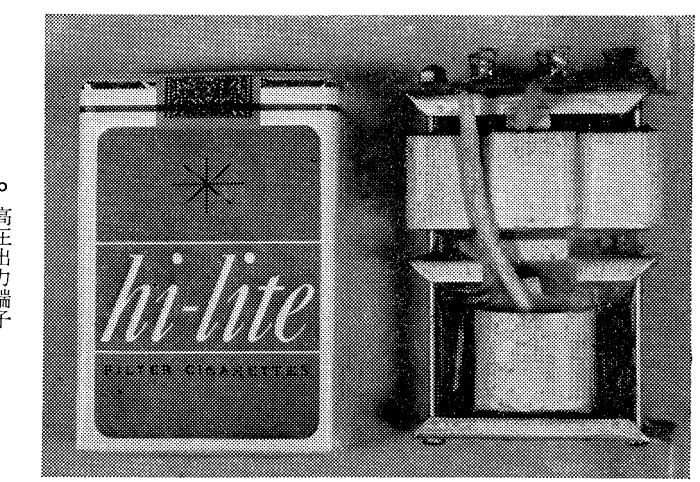

写真 1 制御リアクタの外観 Outer view of the reactor. 


\section{3.リアクタ制御の静特性}

\section{1 静特性の一般的考察}

高圧回路の静特性（レギュレーション特性）は, 図 7 のように表わすととができる。ビーム電流を流さないと きの高圧を $E_{\mathrm{HT}}$ とする。リアクタ制御を行なわないと き，ビーム電流を $I_{\mathrm{HT}}$ だけ流すと高圧は高圧回路が内部 抵抗をむつため， $E_{\mathrm{HT}}$ から $E_{\mathrm{HT}^{\prime}}$ に低下する。 ここで ビーム電流を $I_{\mathrm{HT}}$ だけ流したときの高圧 $E_{\mathrm{HT}^{\prime}}$ をリア クタ制御を行なうととによって $E_{\mathrm{HT}^{\prime}}$ から $E_{\mathrm{HT}^{\prime \prime}}$ まで上 昇させるとする。

また，ビーム電流を $I_{\mathrm{HT}}$ 流した状態で高压制御を行な わない場合の $I_{c p}$ を $I_{c p}{ }^{\prime} ， L_{t}$ を $L_{t}{ }^{\prime}$ とし，リアク夕制 御を行なった場合の $I_{c p} ， L_{t}$ をそれぞれ $I_{c p}{ }^{\prime \prime} ， L_{t}{ }^{\prime \prime}$ と すると，2 章で誘導した $(7),(8)$ 式から容易に次式を 得る.

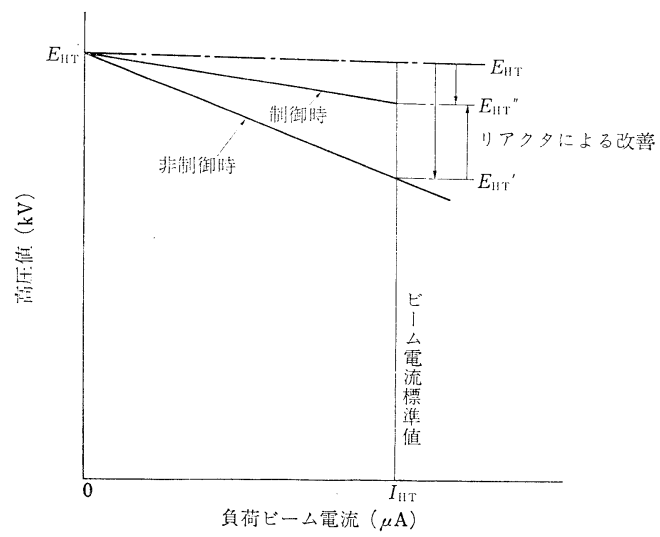

図 7 ビーム電流一高压の静特性 (高圧レギュレーション特性) The high voltage regulation characteristics.

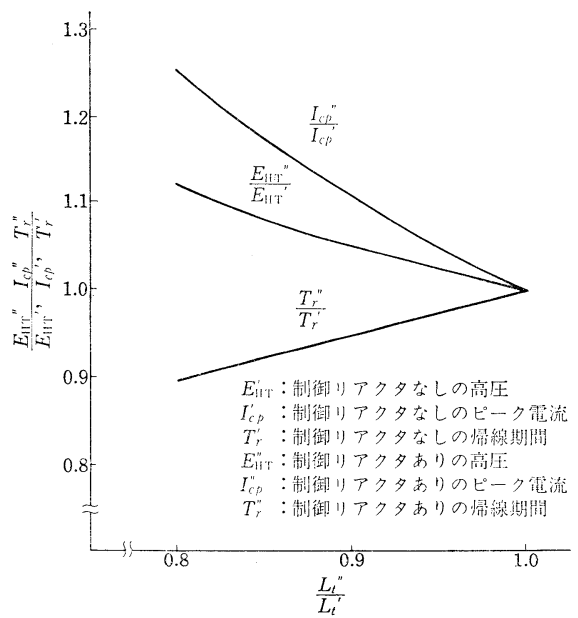

図 8 リアクタ制御による高圧，ピーク電流，帰線期間の 変化 (計算値)

High voltage, peak current of the output transistor and retrace period with the regulating reactor. (calculated value)

$$
\begin{aligned}
& \frac{E_{\mathrm{HT}^{\prime \prime}}}{E_{\mathrm{HT}}{ }^{\prime}}=\sqrt{\frac{L_{t}{ }^{\prime}}{L_{t^{\prime \prime}}}} \\
& \frac{I_{c p}{ }^{\prime \prime}}{I_{c p}{ }^{\prime}}=\frac{L_{t}{ }^{\prime}}{L_{t}{ }^{\prime \prime}}
\end{aligned}
$$

綅線期間 $T_{r}$ は近似的に $(3)$ 式で与えられる周波数 によって定まる周期の $1 / 2$ として求まるので，ビーム電 流 $I_{\mathrm{HT}}$ を流した状態での非制御時, リアクタ制御時の $T_{r}$ をそれぞれ $T_{r^{\prime}}{ }^{\prime}, T_{r^{\prime \prime}}{ }^{\prime \prime}$ とすると，次式を得る.

$$
\frac{T_{r}{ }^{\prime}}{T_{r}{ }^{\prime \prime}} \fallingdotseq \sqrt{\frac{L_{t^{\prime \prime}}}{L_{t}{ }^{\prime}}}
$$

$L_{t}$ を変えたときの $(9),(10),(11)$ 式の関係を図示 すると図 8 のようになる，同図汃ら，たとえば全並列イ ンダクタンスを $L_{t}{ }^{\prime}$ から $L_{t}{ }^{\prime \prime}$ まで減少して $L_{t}{ }^{\prime \prime} / L_{t}{ }^{\prime}=$ 0.9 とすると，高圧 $E_{\mathrm{HT}}$ は $5 \%$ 上昇し，コレクタ電流 $I_{c p}$ は $10 \%$ 増加，帰線期間。 $T_{r}$ は $5 \%$ 短くなる。

\section{2 実用回路の静特性}

図 5 亿示した害用回路のビーム電流-高圧の静特性(高 圧レギュレーション特性）を図 9 亿示す．同図には非制 御時とリアクタ制御時の両方の静特性を示してある。ま た同時に, リアクタの DC 巻線に誤差信号として流す直 流電源電流も示してある。

（1）非制御時の静特性

図 9 から非制御時は

$$
\begin{array}{lr}
\text { ビーム電流 } 0 \text { の場合の高圧 } & E_{\mathrm{HT}}=20.3(\mathrm{kV}) \\
\text { ビーム電流 } 1 \mathrm{~mA} \text { の場合の高圧 } & E_{\mathrm{HT}^{\prime}}=16.9(\mathrm{kV}) \\
\text { 非制御時の高圧変化 } & E_{\mathrm{HT}}-E_{\mathrm{HT}^{\prime}}=3.4(\mathrm{kV}) \\
\text { 非制御時の高压内部抵抗 } & R_{\mathrm{HTO}}=3.4(\mathrm{M} \Omega)
\end{array}
$$

(2) 制御リアクタの設計

つぎに、リアクタ制御を行なってビーム電流を流した 場合の高圧の変化を抑制する。ビーム電流が増加したと き, 制御リアクタの DC 巻線に流れる直流電源電流が増 加してリアクタが飽和に近づき， AC 巻線のインダクタ ンスが減少する.その結果, ビーム電流 $1 \mathrm{~mA}$ のき，全 並列インダクタンスは非制御時の $L_{t^{\prime}}$ からリアクタ制

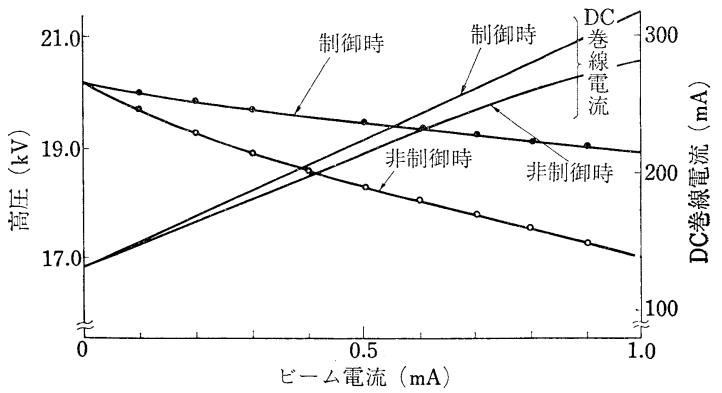

図 9 ビーム電流一高圧の静特性（高压レギュレーション特性） Typical high voltage regulation characteristics. 


\section{カラーテレビジョン装置における新高圧安定系の開発とその動作解析 $\square$ 論 文}

御を行なうことにより $L_{t}{ }^{\prime \prime}$ に減少する。乙れによりビー ム電流 $1 \mathrm{~mA}$ のとき高圧は非制御時の $E_{\mathrm{HT}^{\prime}}$ からリアク タ制御を行なうととにより $E_{\mathrm{HT}^{\prime \prime}}=E_{\mathrm{HT}^{\prime}}{ }^{\prime} \overline{L_{t}{ }^{\prime} / L_{t}{ }^{\prime \prime}}$ まで 上昇し，高圧は安定化される。

次に，リアクタ制御を行なうことで，高圧レギュレー ションをどの程度まで改善する必要があるかを求める.

ビーム電流が変化すると高圧が変わり，このため画面 サイズが変化する，ビーム電流が 0 から最大值まで変わ った場合のサイズ変化の許容値は，従来の実績から $5 \%$ 程度である. サイズ変化は高圧の平方根に逆比例するの で，5\%のサイズ変化は高圧の $10 \%$ 変化に対応する. したがって，ビーム電流による高圧の変化の許容值は $10 \%$ 程度と考える。

図 5 に示した実用回路では，非制御時には，ビーム電 流が 0 から $1 \mathrm{~mA}$ まで変化すると高圧は $20.3 \mathrm{kV}$ から $16.9 \mathrm{kV}$ と約 $17 \%$ 変化する. そこでリアクタ制御を行 なうととによりビーム電流によるサイズ変化を $17 \%$ か ら $10 \%$ に改善する。乙れはビーム電流 $1 \mathrm{~mA}$ のさき 高圧を，制御を行なうことにより $1 \mathrm{kV}$ 上昇させ，

ビーム電流 $1 \mathrm{~mA}$ の場合の高圧 $E_{\mathrm{HT}^{\prime \prime}}=18(\mathrm{kV})$

(リアクタ制御時)

になるように制御リアクタを設計するととである.

$E_{\mathrm{HT}}{ }^{\prime \prime} / E_{\mathrm{HT}^{\prime}}=1.06$ であるから，乙れを実現するため の $L_{t}$ の計算值は図 8 から $L_{t}{ }^{\prime \prime} / L_{t}{ }^{\prime}=0.89$ となる. ま た，同図から $I_{c p}{ }^{\prime \prime} / I_{c p}{ }^{\prime}=1.12 ， T_{r}{ }^{\prime \prime} / T_{r}{ }^{\prime}=0.94$ となる.

以上の計算值を表 1 にまとめて示す。なお，同表には 次に述べる実測值屯同時に示してある.

（3）リアクタ制御時の静特性

前項に示した仕様に基づいて製作したリアクタ制御の 実用回路の静特性は図 9 に示してある. 同図から,リア クタ制御時は,

ビーム電流 0 の場合の高压 $\quad E_{\mathrm{HT}}=20.3(\mathrm{kV})$

ビーム電流 $1 \mathrm{~mA}$ の場合の高圧 $E_{\mathrm{HT}^{\prime \prime}}=18.9(\mathrm{kV})$

リアクタ制御時の高圧変化 $E_{\mathrm{HT}}-E_{\mathrm{HT}^{\prime \prime}}=1.4(\mathrm{kV})$

リアクタ制御時の高圧内部抵抗 $R_{\mathrm{HT}}=1.4(\mathrm{M} \Omega)$ となり，ビーム電流を０から $1 \mathrm{~mA}$ まで変化したときの 高压変化は $7 \%$ 程度であり, 高圧回路の静特性（レギュ レーション特性) は実用上, 問題とならない程度まで改 善されているととがわかる.

表 1 リアクタ制御の計算値と実測值 Comparison between theoretical calculation and experimental results (with the regulating reactor).

\begin{tabular}{l|c|c|c|c|c}
\hline \hline & $\begin{array}{c}E_{\mathrm{HT}}{ }^{\prime \prime}-E_{\mathrm{HT}} \\
(\mathrm{kV})\end{array}$ & $\frac{E_{\mathrm{HT}}{ }^{\prime \prime}}{E_{\mathrm{HT}}}$ & $\frac{L_{t^{\prime \prime}}}{L_{t^{\prime}}}$ & $\frac{I_{c p^{\prime \prime}}}{I_{c p^{\prime}}}$ & $\frac{T_{r^{\prime \prime}}}{T_{r^{\prime}}}$ \\
\hline 計 算 值 & 1.0 & 1.06 & 0.89 & 1.12 & 0.94 \\
実 測 値 & 2.0 & 1.12 & 0.89 & 1.19 & 0.96 \\
\hline
\end{tabular}

第 26 巻 第 3 号 (1972)
な掠，本リアクタ制御方式は，すでにテレビ装置に実 用化されており，高耐圧真空管を使ったシャントレギュ レーター方式のような電力消費がなく，良好な制御特性 が得られ, 信頼度む非常に高いことが実証されつつある.

図9 から求めた $E_{\mathrm{HT}}$ ，また実測した $L_{t}, I_{c p}, T_{r}$ を まとめて表 1 亿示す。表 1 亿は先に求めた計算值屯同様 に示してある。同表から $L_{t}{ }^{\prime \prime} / L_{t}{ }^{\prime}$ の計算值と実測值は 一致しているに屯かかわらず，高圧上昇の㬰測值は計算 值よりもかなり大きくなっている，ての理由は次のよう であると考えられる。

ビーム電流が 0 のところでは，高圧回路の 3 次高調波 条件がほぼ満足されていて，FBT の高圧巻線のリンギ ング電圧が少なく, 一方, ビーム電流が $1 \mathrm{~mA}$ では $L_{t}$ が変化するので高調波条件がくずれて，リンギングを多 少生ずる。乙こで使用している高圧回路では 3 倍圧整流 をしているので, 高圧巻線に生ずる FBT パルスの正の ピーク，执よび負のピークを整流している.

リンギングを生ずると，FBT パルスの負のピーク值 が大きくなるので，高压が上昇するととになる．

以上のような理由で, 試作結果の高圧上昇值は計算值 より大きくなったと推定される。な扔，ビーム電流が 0 のと乙ろで 3 次高調波条件を満足させると, ビーム電流 が $1 \mathrm{~mA}$ のころで条件がくずれてリンギング電压を生 ずるが，乙れは FBT パルスの 1/10 以下で，夷用上問 題はない.

次に， $I_{c p}{ }^{\prime \prime} / I_{c p}{ }^{\prime}$ の実測值が計算值より数\%大きくなっ ているのは，高压が上昇するため FBT 自身の損失が増 大したためと考えられる。

帰線期間 $T_{r}$ の計算值は，リアクタ制御を行なうこと により，数\%変化するが，実際のビーム電流の変化によ っては，次のような理由でほとんよ゙変化しない．

すなわち，非制御時には，ビーム電流が増加すると帰 線期間に共振回路の $Q$ が実効的に低下するため $T_{r}$ は長 くなる，ところが，リアクタ制御時にはビーム電流が増 大し， $L_{t}$ が減少するので $T_{r}$ は短くなる方向である. そのため，先の $Q$ 低下によって $T_{r}$ が長くなる要因とが お互いに相殺し、リアクタ制御を行なった場合には，ビ 一ム電流が変化して屯帰線期間はほとんど変化しない.

\section{4. 非制御時の動特性}

非制御時の高圧回路の動特性を理論的に把握するため に等価回路を誘導し，それから計算される值と実測值を 比較検討する ${ }^{5}$.

\section{1 等価回路の誘導}

図 5 において, 制御リアクタを省略した高圧偏向系は, 次の過程で非制御時の等価回路を作ることができる. 
まず, 出力トランジスタ, ダンパーダイオード, 共振コ ンデンサは水平周期のスイッチング動作のためのもので あるから，図10のようにスイッチに置き換えるととが できる。乙こで $R_{\text {HTO }}$ は非制御時にチョークコイルの内 部抵抗が 0 のきの高圧レギュレーション特性から，ビ 一ム電流が $\Delta I_{\mathrm{HT}}$ 変化したときの高圧の変化を $\Delta E_{\mathrm{HT}}$ とすると， $\Delta E_{\mathrm{HT}} / \Delta I_{\mathrm{HT}}$ として定められた高圧内部抵抗 が導入されている.

次に, 高圧と FBT 1 次側のコレクタパルスの比（こ れはほぼ FBT の 2 次巻数と 1 次巻数の比である)を $n$ として, $R_{\mathrm{HTO}}$, 受像管電極容量 $C_{0}$ を FBT 1 次側に変 換すれば図 11 となる。 $L_{l} ， C_{s}$ は FBT の漏洩インダク タンス，分布容量を 1 次側に変換したものである.さら

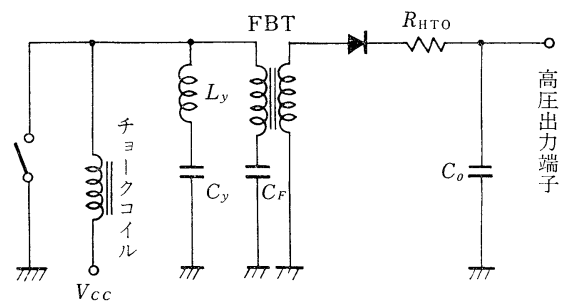

$C_{o}:$ 受像管電極容量

$R_{\mathrm{HTO}}:$ 直流的高圧内部抵抗 (非制御)

図 10 トランジスタ,ダンパーダイオード, 共振コンデン サをスイッチで置き替えた等価回路 (非制御時)

Equivalent circuit of replacing the transistor, the damper diode and the resonating capacitor with a switch. (without the regulating reactor)

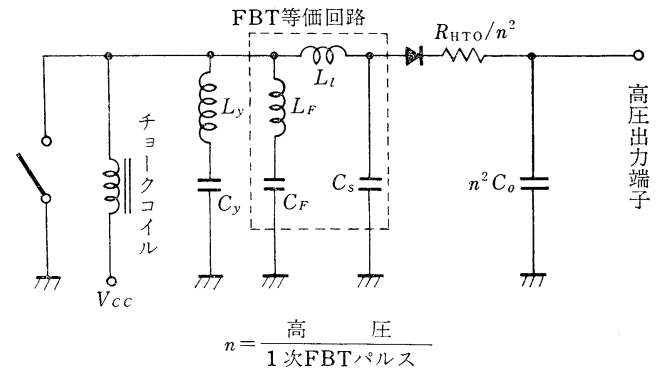

図 11 FBT の 2 次側を 1 次側に置き替えた等価回路 (非制御時) Equivalent circuit changing the secondary of the FBT into the primary. (without the regulating reactor)

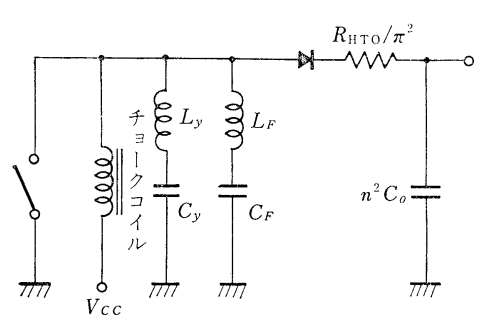

図 12 低周波領域での等価回路 (非制御時) Equivalent circuit of low frequency. (without the regulating reactor)
に動特性として取扱う周波数は，後に示すように，水平 発振周波数に比較して充分低い範囲であるから，FBT の $L_{l}, C_{s}$ を省略することができる.

この段階で図 12 の等価回路が考えられる．乙とで注 意すべきととは，スイッチと整流器である，乙の等価回 路はスイッチングにより生じたフライバックパルスを整 流して高圧を出す動作を考慮に入れてあるので，てのま までは簡単に取扱えない，したがって，次のようにスイ ッチと整流器の動作を置き換える.

整流器の低圧側は電源電圧で動作し, 一方, 高王側 はコレクタパルス電圧で動作しているので, 整流器の高 圧側のインピーダンスをコレクタパルス電圧と電源電圧 $V_{C C}$ の比 $m$ でインピーダンス変換を行なう. その結果, 通常の等価回路として図 13 が得られる。また図 13 では FBT の低圧巻線のインダクタンス $L_{F}$ は, DYのインダ クタンス $L_{y}$ にくらべ充分大きいので省略している.

\section{2 等価回路による動特性の計算}

前節で得られた等価回路が，実際をごの程度説明でき るかを吟味するために，乙の等洒回路を用いて非制御時 の動特性を計算する．図14のようにループ電流をきめ ると，回路方程式は次のようになる。図 14 でダッシュ のついている諸元は，FBT の 2 次側から 1 次側に換算 したあのであることを示している.

$$
\left\{\begin{array}{l}
\left(L_{\mathrm{DC}}+L_{y}\right) \frac{d i_{1}}{d t}+\left(R_{\mathrm{DC}}+R_{y}\right) i_{1}+\frac{1}{C_{y}} \int i_{1} d t \\
-L_{y} \frac{d i_{2}}{d t}-R_{y} i_{2}-\frac{1}{C_{y}} \int i_{2} d t=V_{C C} \\
-L_{y} \frac{d i_{1}}{d t}-R_{y} i_{1}-\frac{1}{C_{y}} \int i_{1} d t+L_{y} \frac{d i_{2}}{d t} \\
+\left(R_{y}+R_{\mathrm{HTO}^{\prime}}\right) i_{2}+\left(\frac{1}{C_{y}}+\frac{1}{C_{0^{\prime}}}\right) \int i_{2} d t \\
=\frac{1}{C_{0^{\prime}}} \int I^{\prime} d t \\
e_{h t^{\prime}}=\frac{1}{C_{0^{\prime}}} \int\left(i_{2}-I^{\prime}\right) d t
\end{array}\right.
$$

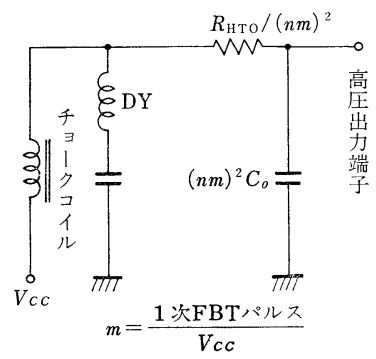

図 13 最終的等価回路 (非制御時) Final equivalent circuit. (without the regulating reactor)

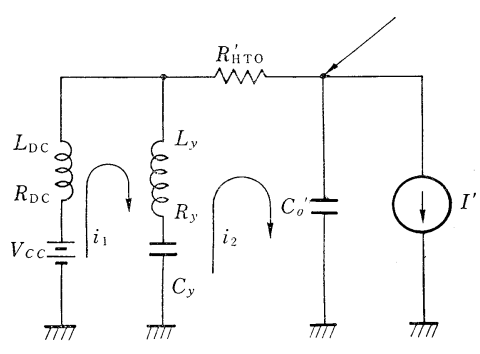

ただし $R_{\text {HTo }}^{\prime}, C_{o}^{\prime}$ の值は各及 $R_{\mathrm{HTO}} /(n m)^{2},(n m)^{2} C_{0}$ である

図 14 非制御時の等価回路 Equivalent circuit without the regulating reactor. 
初期条件として

$$
\begin{aligned}
& i_{1}(0)=i_{2}(0)=0 \\
& \frac{1}{C_{y}} \int\left(i_{1}-i_{2}\right) d t=V_{C C}
\end{aligned}
$$

$$
\frac{1}{C_{0}{ }^{\prime}} \int i_{2} d t=V_{C C}
$$

この回路方程式をラプラス変換して $e_{n t}{ }^{\prime}$ につて解け ば次式を得る。ここで $E_{\mathrm{HT}^{\prime}}(s)=\mathcal{L}\left[e_{h t}{ }^{\prime}(t)\right], I^{\prime}(s)=\mathcal{L}$ 〔I’である。

$$
\begin{aligned}
E_{\mathrm{HT}^{\prime}}(s)=- & \frac{L_{\mathrm{DC}} L_{y} s^{3}+\left(R_{\mathrm{DC}} L_{y}+R_{y} L_{\mathrm{DC}}+R_{\mathrm{HTO}} L_{\mathrm{DC}}+R_{\mathrm{HTO}^{\prime}} L_{y}\right) s^{2}+\left(R_{y} R_{\mathrm{DC}}+R_{\mathrm{HTO}} R_{\mathrm{DC}}+R_{\mathrm{HTO}^{\prime}} R_{y}+L_{\mathrm{DC}} / C_{y}\right) s}{\left.L_{\mathrm{DC}} L_{y} s^{4}+\left(R_{\mathrm{DC}} L_{y}+R_{y} L_{y}+R_{\mathrm{HTO}} L_{\mathrm{DC}}+R_{\mathrm{HTO}^{\prime}} L_{y}\right) s^{3}+\left(R_{y} R_{\mathrm{DC}}+R_{\mathrm{HTO}} R_{\mathrm{DC}} / C_{y}+L_{\mathrm{DC}} / C_{0}{ }^{\prime}+L_{y} / C_{0}\right)^{\prime}\right) s^{2}} * \\
& * \frac{+\left(R_{\mathrm{HTO}} / C_{y}+R_{\mathrm{DC}} / C_{y}\right)}{+\left(R_{\mathrm{HTO}} / C_{y}+R_{\mathrm{DC}} / C_{y}+R_{\mathrm{DC}} / C_{0}{ }^{\prime}+R_{y} / C_{0}^{\prime}\right) s+1 /\left(C_{0}{ }^{\prime} \cdot C_{y}\right)} \cdot \frac{I^{\prime}(s)}{C_{0^{\prime}}}+\frac{V_{C C}}{s}
\end{aligned}
$$

図 5 の実用回路に㧍いて具体的な数值は， $R_{\mathrm{DC}}=13.6$ $\Omega, R_{y}=1.8 \Omega, n=25, m=65$ として, $R_{\mathrm{HTO}^{\prime}}=133 \Omega$ (この值は高圧内部抵抗 $3.4 \mathrm{M} \Omega$ に対応する)， $L_{\mathrm{DC}}=40$ $\mathrm{mH}, L_{y}=1.7 \mathrm{mH}, C_{y}=0.68 \mu \mathrm{F}, C_{0}{ }^{\prime}=29.4 \mu \mathrm{F}$ (とれ は受像管電極容量 $1115 \mathrm{pF}$ に対応する) である。ここで $R_{\mathrm{HTO}}{ }^{\prime}$ の值は $R_{\mathrm{DC}}=0$ のときの高圧内部抵抗であるが, $R_{\mathrm{DC}}$ は $13.6 \Omega$ であり, $R_{\mathrm{HTO}}$ の $133 \Omega$ くらべ小さい ので， $R_{\mathrm{DC}}=13.6 \Omega$ のときの $R_{\mathrm{HTO}}{ }^{\prime}$ の值で近似した. 以後，等価回路に打ける $R_{\mathrm{HTO}}{ }^{\prime}$ の值は，ある $R_{\mathrm{DC}}$ の高 圧制御なしのときの高圧内部抵抗の值とする。乙れらの 值から計算すると $E_{\mathrm{HT}^{\prime}}(s)$ は次のようになる.

$E_{\mathrm{HT}^{\prime}}(s)=-\frac{\left(s+0.67 \times 10^{5}\right)}{\left(s+0.25 \times 10^{3}\right)} *$

$* \frac{\left(s^{2}+1.2 \times 10^{4} s+4.5 \times 10^{7}\right)}{\left(s+0.66 \times 10^{5}\right)\left(s^{2}+1.2 \times 10^{4} s+4.2 \times 10^{7}\right)}$

- $\frac{I^{\prime}(s)}{C_{0^{\prime}}}+\frac{V_{C C}}{s} \simeq-\frac{33 \times 10^{3}}{\left(s+0.25 \times 10^{3}\right)} \cdot I^{\prime}(s)+\frac{V_{C C}}{s}$

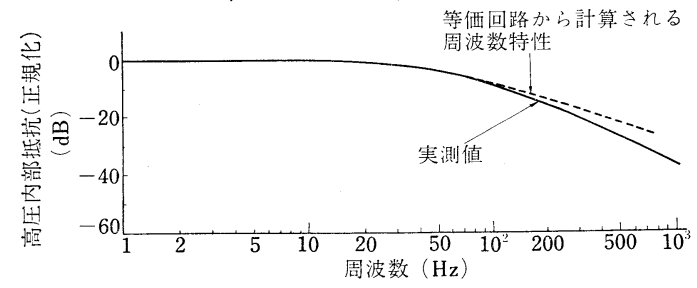

図 15 高厈内部抵抗の周波数特性の理諭值と実測值の比較 (非制御時)

Comparison between theoretical calculation and experimental results of the high voltage internal resistance versus frequency. (without the regulating reactor)

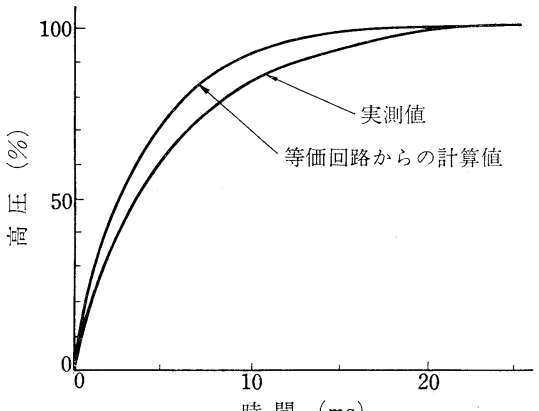

時 間 $(\mathrm{ms})$

図 16 ステップ応答の理論値己害測値の比較 (非制御時) Comparison between theoretical calculation and experimental results of the step response. (without the regulating reactor)
$I^{\prime}(s)-E_{\mathrm{HT}^{\prime}}(s)$ の周波数特性をこの計算式から描けば 図 15 のように，1 次遅れの特性を示し，200 Hz 程度で 高圧内部抵抗は $1 / 10$ に減少する。したがって，レギュ レーションの改善は $200 \mathrm{~Hz}$ 以下の低い周波数範囲で考 えればよいことがわかる。ビーム電流一高圧のステップ 応答を計算すれば図 16 のようになる。乙れらの図から 実測值と等洒回路による計算とはよく一致している.

\section{5.リアクタ制御時の動特性}

前章と同じように，リアクタ制御時の動特性を等価回 路を誘導して計算し, 実測值との比較検討を行なう ${ }^{5)}$.

\section{1 等価回路の誘導}

前章の等価回路誘導と同じ過程を踏むととによって， リアクタ制御時の等価回路を誘導できるが，リアクタ動 作の表現をどのようにするかが問題となる，そこで，次 のように考えて，リアクタ動作を考虑した等価回路を得 るととができる.

まず，ビーム電流 $I_{\mathrm{HT}}$ が変化したとき，それに応じて リアクタ $\mathrm{DC}$ 巻線電流 $I_{\mathrm{DC}}$ が変化する $\left(I_{\mathrm{HT}}\right.$ と $I_{\mathrm{DC}}$ の 間には時間遅れがある). 次に $I_{\mathrm{DC}}$ が変化すると,リア クタ $\mathrm{AC}$ 巻線のインダクタンスが瞬時に変化する。 そし てコレクタパルス電圧が瞬時に変化して高圧低下を補な っている.

高压レギュレーション特性を図 17 のモデルで考える. ある $I_{\mathrm{HT}}$ に㧍ける非制御時および制御時の高圧を，おの おの $E_{\mathrm{H} 1 \mathrm{O}}, E_{\mathrm{HT}}$ とし， $I_{\mathrm{HT}}$ を $\Delta I_{\mathrm{HT}}$ 変化させたときの 高圧をそれぞれ $E_{\mathrm{HTO}}-\Delta E_{\mathrm{HTO}}, E_{\mathrm{HT}}-\Delta E_{\mathrm{HT}}$ とする. 非制御時および制御時の高压内部抵抗をそれぞれ $R_{\text {HTO }}$, $R_{\mathrm{HT}}$ とすれば，制御時の高圧低下分 $\Delta E_{\mathrm{HT}}$ は，

$$
\Delta E_{\mathrm{HT}}=R_{\mathrm{HT}} \cdot \Delta I_{\mathrm{HT}}
$$

となる。乙とで $R_{\mathrm{HT}}=\tan ^{-1} \beta$ である，乙の值はまた次 のように書き表わすことができる。

$$
\begin{aligned}
\Delta E_{\mathrm{HT}} & =R_{\mathrm{HTO}} \cdot \Delta I_{\mathrm{HT}}-\left(R_{\mathrm{HTO}}-R_{\mathrm{HT}}\right) \cdot \Delta I_{\mathrm{HT}} \\
& =R_{\mathrm{HTO}} \cdot \Delta I_{\mathrm{HT}}-K \cdot \Delta I_{\mathrm{HT}}
\end{aligned}
$$

ここで $R_{\mathrm{HTO}}=\tan ^{-1} \alpha$ である. 上式は次のように言い表 わすととができる，制御時の高圧低下は非制御時の高圧 低下 $R_{\mathrm{HTO}} \cdot \Delta I_{\mathrm{HT}}$ から $K \cdot \Delta I_{\mathrm{HT}}$ だけひいた值である. 


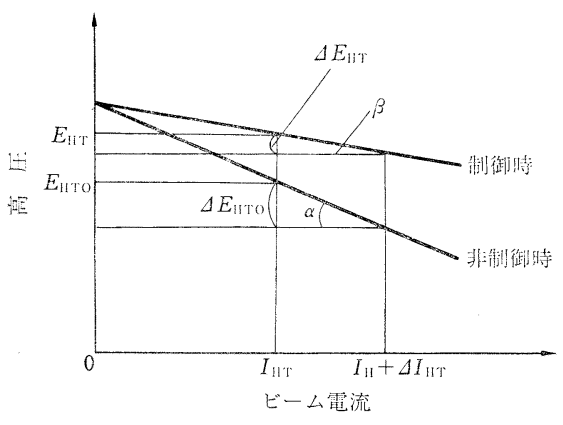

図 17 高压レギュレーション特性モデル

Model of the high voltage regulation characteristics.

この $K \cdot I_{\mathrm{HT}}$ がリアクタ制御により改善された分であ る.

また，高圧は前述のように FBT 1 次側の全並列イン ダクタンスの関数として表わされる。したがって，図14 に示す等価回路に勃汀る高压 $e_{h t}{ }^{\prime}$ は,

$$
e_{h t^{\prime}}=f\left(L_{t}\left(I_{\mathrm{DC}}\right)\right)
$$

ここで $I_{\mathrm{DC}}$ は DC 巻線に流れる電流である. リアク タの動作によって高压の低下は補なわれ，その大きさ $\Delta$ は線形近似をすれば，

$$
\Delta=\frac{\partial f}{\partial L_{t}} \cdot \frac{\partial L_{t}}{\partial I_{\mathrm{DC}}} \cdot \Delta I_{\mathrm{DC}}=-K^{\prime} \cdot \Delta I_{\mathrm{DC}}
$$

となる.以上から,リアクタの動作によって電源電流の変 化に比例した大きさだけ高圧低下が補なわれると考えら れる. その結果，図 18 の制御時の等価回路が得られる.

ここで新しく導入された定数 $K^{\prime}$ は，

$$
K^{\prime}=\frac{K}{(m n)^{2}}
$$

で $K$ を 1 次側に換算した值である。

$$
\begin{aligned}
E_{\mathrm{HT}^{\prime}}(s)= & -\frac{L_{\mathrm{DC}} L_{y} s^{3}+\left(R_{\mathrm{DC}} L_{y}+R_{y} L_{\mathrm{DC}}+R_{\mathrm{HTO}} L_{\mathrm{DC}}+R_{\mathrm{HTO}} L_{y}-K^{\prime} L_{y}\right) s^{2}}{L_{\mathrm{DC}} L_{y} s^{4}+\left(R_{\mathrm{DC}} L_{y}+R_{y} L_{\mathrm{DC}}+R_{\mathrm{HTO}} L_{\mathrm{DC}}+R_{\mathrm{HTO}} L_{y}-K^{\prime} L_{y}\right) s^{3}} * \\
* & \frac{+\left(R_{y} R_{\mathrm{DC}}+R_{\mathrm{HTO}} R_{\mathrm{DC}}+R_{\mathrm{HTO}} R_{y}+L_{\mathrm{DC}} / C_{y}-K^{\prime} R_{y}\right) s}{+\left(R_{y} R_{\mathrm{DC}}+R_{\mathrm{HTO}} R_{\mathrm{DC}}+R_{\mathrm{HTO}} R_{y}+L_{\mathrm{DC}} / C_{y}+L_{\mathrm{DC}} / C_{0}{ }^{\prime}+L_{y} / C_{0}{ }^{\prime}-K^{\prime} R_{y}\right) s^{2}} * \\
* & \frac{+\left(R_{\mathrm{HTO}}+R_{\mathrm{DC}}-K^{\prime}\right) C_{y}}{\left.+\left(R_{\mathrm{HTO}} / C_{y}+R_{\mathrm{DC}} / C_{y}+R_{\mathrm{DC}} / C_{0}{ }^{\prime}+R_{y} / C_{0}{ }^{\prime}-K^{\prime} / C_{y}\right) s+1 /\left(C_{y} \cdot C_{0}\right)^{\prime}\right)} \cdot \frac{I^{\prime}(s)}{C_{0}{ }^{\prime}}+\frac{V_{C C}}{s}
\end{aligned}
$$

となる. $K^{\prime}$ に $K=\left(R_{\mathrm{HTO}}-R_{\mathrm{HT}}\right)=(3.4-1.4) \times 10^{6} \Omega$ を $(m n)^{2}$ で割って 1 次側に換算した值 $76 \Omega$ を代入して計 算すれば，

$$
\begin{aligned}
E_{\mathrm{HT}^{\prime}}(s)= & -\frac{\left(s+0.141 \times 10^{4}\right)}{\left(s^{2}+1.29 \times 10^{3} s+8.97 \times 10^{5}\right)} * \\
& * \frac{\left(s+0.145 \times 10^{5}\right)\left(s+0.516 \times 10^{5}\right)}{\left(s+0.159 \times 10^{5}\right)\left(s+0.497 \times 10^{5}\right)} \cdot \frac{I^{\prime}(s)}{C_{0}^{\prime}} \\
& +\frac{V_{C C}}{s} \simeq \frac{-48.3 \times 10^{3}\left(s+0.141 \times 10^{4}\right)}{s^{2}+1.29 \times 10^{3} s+8.97 \times 10^{5}} \\
& \times I^{\prime}(s)+\frac{V_{C C}}{s}
\end{aligned}
$$

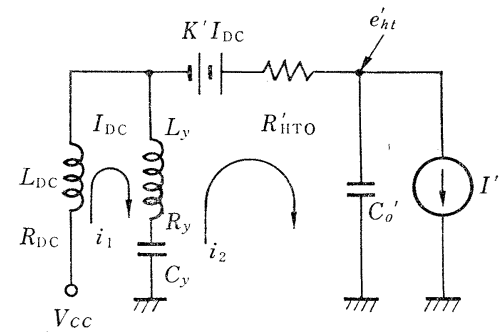

図 18 リアクタ制御時の等価回路 Equivalent circuit with the regutating reactor.

\section{2 等価回路による動特性の計算}

得られた等佂回路を用いて動特性を計算し, 実測值と 比較検討した。この等価回路のループ電流を図 18 のよ うに定めれば，回路方程式は，

$$
\begin{aligned}
& \left(L_{\mathrm{DC}}+L_{y}\right) \frac{d i_{1}}{d t}+\left(R_{\mathrm{DC}}+R_{y}\right) i_{1}+\frac{1}{C_{y}} \int i_{1} d t \\
& -L_{y} \frac{d i_{2}}{d t}-R_{y} i_{2}-\frac{1}{C_{y}} \int i_{2} d t=V_{C C} \\
& -L_{y} \frac{d i_{1}}{d t}-R_{y} i_{1}-\frac{1}{C_{y}} \int i_{1} d t+L_{y} \frac{d i_{2}}{d t} \\
& +\left(R_{y}+R_{\mathrm{HTO}^{\prime}}\right) i_{2}+\left(\frac{1}{C_{y}}+\frac{1}{C_{0}}\right) \int i_{2} d t \\
& =\frac{1}{C_{0}{ }^{\prime}} \int I^{\prime} d t+K^{\prime} i_{1} \\
& e_{h t^{\prime}}=\frac{1}{C_{0}{ }^{\prime}} \int\left(i_{2}-I^{\prime}\right) d t
\end{aligned}
$$

となる。初期条件は 4.2 節と同じである。乙れをラプラ ス変魥して $E_{\mathrm{HT}^{\prime}}(s)$ について解けば,
となる。上式から計算される周波数特性, ステップ応答 はそれぞれ図 19, 図 20 のようになる。実測值亡計算值 は多少異なっている。乙の原因として，等洒回路の導入 で FBT 3 次高調波を何ら考慮していないとと, リアク タの動作を DC 巻線電流に比例した電圧上昇で代表し, リアクタの非直線性を考慮していないとと等が考えられ る.しかし，乙の等価回路は完全なものではないが，実 際の現象を良く説明できると考えられる。

\section{3 等価回路による動特性の考察}

いままで述べたように，等価回路から計算值は実測值 


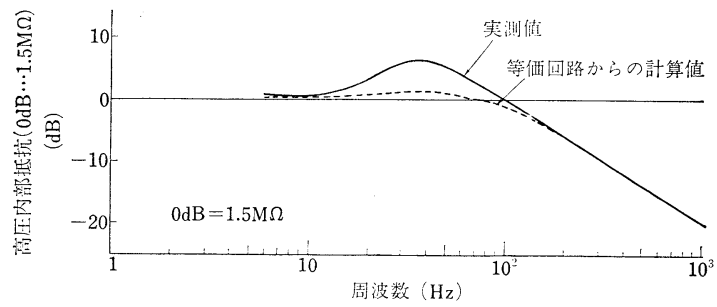

図 19 高圧内部抵抗の周波数特性の計算值と実測値の比 較 (リアクタ制御時)

Comparison between theoretical calculation and experimental results of the hight voltage internal resistance versus frequency. (with the regulating reactor)

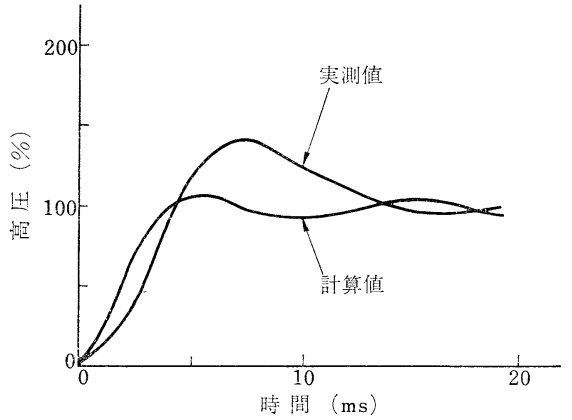

図 20 ステップ応答の計算値と実測值の比較 (リアクタ制御時)

Comparison between theoretical calculation and experimental results of the step response. (with the regulating reactor)

とほぼ一致することがわかった。この等価回路はかなり 複雑なので，各回路定数が高圧の過渡特性によ゙う影響を 及ぼしているかわかりにくい，そこで，DY 枝路のイン ピーダンスは他の枝路のインピーダンスに比較して考え ている周波数範囲で大きいので省略して考える．その結 果，図 18 の等価回路は図 21 のように簡単なすのとな る。ここで図 18 の等価電压源 $K^{\prime} I_{\mathrm{DC}}$ は DY 枝路它省 略した結果，一自角性抵抗となる。

この等価回路から $E_{\mathrm{HT}^{\prime}}(s)$ を計算すると,

$$
\begin{aligned}
E_{\mathrm{HT}^{\prime}}(s)= & \frac{L_{\mathrm{DC} S}+\left(R_{\mathrm{HTO}^{\prime}}-K^{\prime}\right)}{L_{\mathrm{DC} s^{2}}+\left(R_{\mathrm{HTO}}{ }^{\prime}-K^{\prime}\right) s+\left(1 / C_{0^{\prime}}\right)} \\
& \cdot \frac{I^{\prime}(s)}{C_{0}{ }^{\prime}}+\frac{V_{C C}}{s}
\end{aligned}
$$

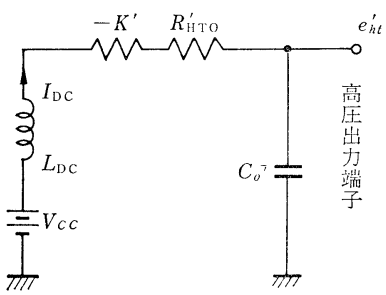

図 21 簡略化した制御時 の等洒回路

Simplified equivalent circuit with the regulaling reactor.
となる，との等価回路から次のことがわかる。

（1）振動性と安定性について

(30)式から高圧は

$$
\left(R_{\mathrm{HTO}^{\prime}}-K^{\prime}\right)^{2}-\frac{4 L_{\mathrm{DC}}}{C_{0}{ }^{\prime}}<0
$$

のとき振動解となる。また安定限界は，

$$
R_{\text {HTo }^{\prime}}-K^{\prime}=0
$$

のときである．以上から，制御時の高圧内部抵抗を必要 以上に小さくしすぎると高圧は振動しやすくなり，その 值が 0 以下となると不安定になることがわかる.

（2）高圧の過渡応答に関しては，高圧内部抵抗が大 きく関係している。したがって，応答時間については総 合性能で最適点を選定する必要がある。

\section{6.むす び}

カラーテレビ装置の高圧を，可飽和リアクタを用いて 安定化する，まったく新しい方式（本文ではリアクタ制 御之略称している）の動作原理，実用回路，動特性につ いて述べた。リアクタ制御方式は，可飽和リアクタを使 用して水平出力トランスの低圧側で高圧を安定化するた め, 従来の高耐圧真空管を用いて高圧側で制御するシャ ントレギュレーター方式にくらべ，電力消費が少なく， 信頼度が非常に高い。

また，動特性を解析するため，等価回路を誘導した。 その結果, レギュレーション特性を必要以上に改善する と，過渡応答が振動的になりやすい。したがって，レギ ュレーションの改善の程度については, 総合性能で最適 点を選定する必要がある。

最後に，日頃ご指導いただく日立製作所，家電研究所 須藤卓郎所長，宇佐美襄副所長に感謝いたします。

（昭和 46 年 4 月 12 日受付）

\section{〔参 考 文 献〕}

1）広田，松本，藤島，宮崎：可飽和リアクタを用いた新高圧安定 回路，テレビ全大予 (1969)

2) 山田ほか: テレビジョン高圧制御回路，テレビ全大予 (1970)

3) W.F. Dietz: A Horizontal Sawtooth Current and High Voltage Generator for Magnetically Deflected Kinescope, IEEE Trans., RTB-9, 2, Nov. (1968)

4) R. Hirota, G. Miyazaki and T. Fujishima: New High Voltage Regulation Systems for All Solid-State Color Television Receivers, IEEE Trans, BTR-16, May (1970)

5) K. Akashi, R. Hirota and G. Miyazaki: Analysis of New High Voltage Regulation System for All Solid-state Color Television Receivers，回路とシステム理論汇関する京都国際 会議予稿集 $(1970.9)$ 